\title{
Crop optimization and pre-steps standardization to get a Bipolaris euphorbiae-based bioherbicide ${ }^{1}$
}

\author{
Ana Carolina Ribeiro Machado ${ }^{2}$, Dinalva Alves $\mathrm{Mochi}^{2}$, Antonio Carlos Monteiro ${ }^{2}$
}

\section{RESUMO}

Otimização do cultivo e padronização de pré-etapas para a obtenção de bioherbicida à base de Bipolaris euphorbiae

Disponibilizar bioprodutos para o mercado implica em buscar processos adequados para a produção massal e formulação de agentes biológicos. Neste trabalho, foi examinada a produção de Bipolaris euphorbiae em meio sólido (fermentação em substrato sólido) e em sistema bifásico (cultivo em meio líquido seguido de cultivo em meio sólido), e determinados os processos de secagem e coleta de conídios, em condições de laboratório. Investigou-se a influência do período de incubação e a quantidade de inóculo. A secagem dos conídios foi realizada por meio de estufa $\left(30^{\circ} \mathrm{C}, 35^{\circ} \mathrm{C}\right.$, $40^{\circ} \mathrm{C}, 45^{\circ} \mathrm{C}, 50^{\circ} \mathrm{C}, 55^{\circ} \mathrm{C}$ e $60^{\circ} \mathrm{C}$ ) e fluxo laminar, fluxo contínuo de ar e câmara asséptica em temperatura ambiente. Os conídios secos foram obtidos por peneiramento e moagem em moinho de esfera, de martelo ou de grãos. Avaliou-se a viabilidade dos conídios e a esporulação no meio sólido e sistema bifásico. Considerando-se o período de crescimento, a melhor esporulação no meio sólido foi

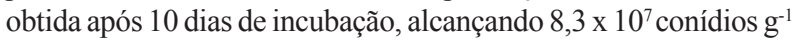
de substrato. O sistema bifásico não incrementou a esporulação de B. euphorbiae $\left(4,5 \times 10^{7}\right.$ conídios $\mathrm{g}^{-1}$ de substrato) cultivado por 14 dias, e a quantidade de inóculo líquido usado neste sistema não foi determinante para incrementar a sua produção. O fluxo contínuo de ar e o fluxo laminar mantiveram a viabilidade dos conídios $(94,6 \%$ e $99,1 \%$, respectivamente) e promoveram grande perda de umidade $(62,6 \%$ e $54,0 \%$, respectivamente). Todos os processos de moagem reduziram a germinação dos conídios $(86,2 \%, 10,5 \%$ e $12 \%$, respectivamente), enquanto o peneiramento proporcionou a coleta de conídios em pó com alta viabilidade $(94,8 \%)$.

PALAVRAS-CHAVE: Produção massal; bioprodutos; coleta de conídios.

\section{INTRODUCTION}

In agricultural environments, weeds compete directly and indirectly with economically important crops, reducing their yield, interfering with harvesting operations and acting as alternative hosts for insect pests and pathogens, in addition to affecting the quality

\section{ABSTRACT}

Making bioproducts available to the market requires finding appropriate processes for mass production and formulation of biological agents. This study aimed at evaluating the Bipolaris euphorbiae production in a solid medium (fermentation in solid substrate) and in a biphasic system (growth in a liquid medium followed by growth in a solid medium), as well as determining the processes for collecting and drying conidia, under laboratory conditions. The influence of the incubation period and inoculum quantity were also investigated. The conidia were dried by using an oven $\left(30^{\circ} \mathrm{C}, 35^{\circ} \mathrm{C}, 40^{\circ} \mathrm{C}, 45^{\circ} \mathrm{C}, 50^{\circ} \mathrm{C}, 55^{\circ} \mathrm{C}\right.$ and $\left.60^{\circ} \mathrm{C}\right)$, and laminar flow, continuous air flow and aseptic chamber at room temperature. Dry conidia were obtained by sieving and grinding in a ball mill, hammer mill or grain grinder. The conidia viability and sporulation efficiency were evaluated in the solid medium and in the biphasic system. For growth period, the best sporulation on solid medium was obtained after 10 days of incubation, reaching $8.3 \times 10^{7}$ conidia $\mathrm{g}^{-1}$ of substrate. The biphasic system did not increase the $B$. euphorbiae sporulation ( $4.5 \times 10^{7}$ conidia $\mathrm{g}^{-1}$ of substrate), after 14 days, and the amount of liquid inoculum used in this system was not an important factor for increasing its production. The continuous air flow and laminar flow preserved the conidial viability $(94.6 \%$ and $99.1 \%$, respectively), while promoting a great moisture loss $(62.6 \%$ and $54.0 \%$, respectively). All the grinding processes reduced the conidia germination $(86.2 \%, 10.5 \%$ and $12 \%$, respectively), while sieving allowed the collecting of powdered conidia with high viability $(94.8 \%)$.

KEY-WORDS: Mass production; bioproducts; conidia collecting.

of the harvested product (Barreto 2009). The weeds interference is responsible for reducing the agricultural production in 30-40\% in the tropics (Lorenzi 2000), and it represents the largest barrier to food production, in many regions of the world (Muzik 1970).

Euphorbia heterophylla L. (Euphorbiaceae), popularly known as milkweed or wild poinsettia, is

1. Article received in Mar./2013 and accepted for publication in Nov./2013 (Registration number: PAT 23018).

2. Universidade Estadual Paulista (Unesp), Faculdade de Ciências Agrárias e Veterinárias, Departamento de Produção Vegetal, Jaboticabal, SP, Brasil.E-mails: biokarol@hotmail.com,dmochi@hotmail.com, montecar@fcav.unesp.br. 
one of the weeds most feared by soybean producers, because of the damage it can cause and the difficulty for controlling it (Brighenti \& Oliveira 2011). Currently, the E. heterophylla control is mainly performed with the aid of herbicides that inhibit the enzymes acetolactate synthase (ALS) and protoporphyrinogen oxidase (PROTOX) (Vidal \& Merotto Júnior 2001).

The recurrent use of certain herbicides, or herbicides with similar mechanisms of action, in the same area has led to the selection of weed populations that are resistant to certain chemical groups and that become difficult to control (Oliveira Júnior \& Inoue 2011). For E. heterophylla, biotypes resistant to ALS inhibitors, or with multiple resistances to ALS and PROTOX inhibitors (Trezzi et al. 2005) and glyphosate (Vidal et al. 2007), have been identified. Moreover, environmental problems, such as contamination of food, soil and water, biological imbalances and toxicity to farmers, are among the additional consequences of the intensive and indiscriminate use of chemical pesticides. Such situations make the use of biological agents for weed control particularly attractive (Fontes 1992), following a global tendency towards seeking alternative control systems that are simultaneously effective, economic and less harmful to the environment.

The use of bioherbicides represents a strategic component of integrated weed management programs, and the Bipolaris euphorbiae Muschovej \& Carvalho fungus is a potential agent for the biological control of E. heterophylla. This fungus may cause, under ideal conditions, plant diseases that result in severe defoliation, stem damage and death of the host (Barreto \& Evans 1998). However, there are still limitations that prevent the use of bioproducts in the field, particularly with respect to large scale production and methods of product storage. Thus, it is essential to develop formulations that overcome such limitations (Almeida et al. 2007).

Mass production at low cost and under controlled conditions is an important step towards ensuring that large quantities of the pathogen can be obtained (Moino Júnior 2000, Lima et al. 2010). In order to enable this production, Penariol et al. (2008) investigated liquid and solid media obtained from grains, grain derivatives and agro-industry wastes. The combination of these substrates were also evaluated for increasing the production of the fungus in a solid medium and in a biphasic culture system (Moraes 2009). However, the biphasic system did not increase its production. Moraes (2009) suggests that this result may be a consequence of an inadequate incubation period, or an insufficient amount of liquid inoculum used to seed the solid medium. Nevertheless, these cultivation aspects need to be investigated.

In the bioproduct production process, drying and obtaining infective units constitute important preliminary stages of the product formulation. It is extremely important to maintain the pathogen in infectious and dormant stages that are safe and easy to use. The keys to the prolonged pathogen survival are preventing germination and reducing metabolism as much as possible (Horaczek \& Viernstein 2004). For this purpose, water extraction is necessary, so that the conidia keep a moisture content of $5-10 \%$, and then can be extracted from the substrate (Silva \& Mello 2007).

Given the need for more studies focused on the various stages of bioproduct manufacturing, the present study aimed to optimise the conditions for the mass production of $B$. euphorbiae, on a solid medium or biphasic system, and to identify appropriate processes for drying and collecting conidia, while preserving their viability.

\section{MATERIAL AND METHODS}

The isolate FCAV \#569 of B. euphorbiae used in this study was maintained in a stock culture, in laboratory. For being used in the assays, the fungus was cultured on plates containing minimal Pontecorvo medium $\left(\mathrm{NaNO}_{3}=6.0 \mathrm{~g} ; \mathrm{KH}_{2} \mathrm{PO}_{4}=1.52 \mathrm{~g} ; \mathrm{MgSO}_{4}\right.$ $7 \mathrm{H}_{2} \mathrm{O}=0.52 \mathrm{~g} ; \mathrm{KCl}=0.52 \mathrm{~g} ; \mathrm{FeSO}_{4}=0.01 \mathrm{~g} ; \mathrm{ZnSO}_{4}=$ $0.01 \mathrm{~g}$; glucose $=10 \mathrm{~g}$; agar $=15 \mathrm{~g}$; distilled water $=$ $1,000 \mathrm{~mL}$ ) (Pontecorvo et al. 1953), modified by Penariol et al. (2008), with the addition of peptone $\left(2.0 \mathrm{~g} \mathrm{~L}^{-1}\right)$ and the substitution of glucose by starch $\left(10 \mathrm{~g} \mathrm{~L}^{-1}\right)$. The fungus was grown in an incubator, for 10 days, at $25^{\circ} \mathrm{C} \pm 0.5^{\circ} \mathrm{C}$, with a 12-hour photoperiod provided by four fluorescent lamps of $20 \mathrm{~W}$. The assays were conducted from January to December 2011, in Jaboticabal, São Paulo State, Brazil.

The substrates were used in a 60:40 proportion, based on dry weight $\left(\mathrm{g} \mathrm{g}^{-1}\right)$. To prepare them, $30 \mathrm{~g}$ of soybean hulls were soaked in distilled water, at a 3:1 ratio $\left(\mathrm{v} \mathrm{w}^{-1}\right)$, for 15 minutes, and then strained to remove the water excess, and $20 \mathrm{~g}$ of sorghum grain 
were cooked in heated distilled water, at a 3:1 ratio $\left(\mathrm{v} \mathrm{W}^{-1}\right)$, for 5 minutes, in low heat. The substrates were mixed and placed in $250 \mathrm{~mL}$ Erlenmeyer flasks. The medium was autoclaved at $121^{\circ} \mathrm{C}$ and $1 \mathrm{kgf} \mathrm{cm}^{-2}$, for 40 minutes. The cultures were inoculated by using a nickel-chrome needle to transfer three $8 \mathrm{~mm}$ diameter disks taken from colonies grown on modified minimal Pontecorvo medium. The flasks were maintained in an incubator, at $25^{\circ} \mathrm{C} \pm 0.5^{\circ} \mathrm{C}$, for $5,6,7,8,9,10,11$, 12,13 and 14 days, with a photoperiod of 12 hours.

For this assay, growth in a liquid medium was followed by growth in a solid medium. The liquid medium consisted of $8 \%$ of sugarcane molasses obtained from dilution in distilled water.

The liquid medium (100 mL) was placed in Erlenmeyer flasks and autoclaved at $121^{\circ} \mathrm{C}$ and $1 \mathrm{kgf} \mathrm{cm}^{-2}$, for 20 minutes. The fungus was inoculated as described above, and incubated at $25^{\circ} \mathrm{C} \pm 0.5^{\circ} \mathrm{C}$, for $3,4,5,6,7,8,9$ and 10 days, with a photoperiod of 12 hours. After the specified period, the mycelial mass that had formed was ground in a SB 40 Black \& Decker ${ }^{\circledR}$ vertical mixer, for 3 seconds, and then strained in a sieve with $1 \mathrm{~mm}$ mesh, resulting in a suspension of conidia and mycelium fragments. This suspension was used to inoculate the solid medium at $3 \mathrm{~mL}$ per flask (Machado et al. 2010). The solid medium was prepared by mixing soybean hull and sorghum grain, and placed in $250 \mathrm{~mL}$ Erlenmeyer flasks, as previously described. The flasks were maintained at $25^{\circ} \mathrm{C} \pm 0.5^{\circ} \mathrm{C}$, for $5,6,7,8,9$ and 10 days, with a photoperiod of 12 hours.

Conidia yield and viability were evaluated at the end of the assay with only solid medium and of the assay with the biphasic cultivation. Samples with $1 \mathrm{~g}$ of solid substrate + fungus were transfered to tubes containing $9 \mathrm{~mL}$ of Tween $80^{\circledR}$ solution $\left(0.1 \% \mathrm{v} \mathrm{v}^{-1}\right)$. The tubes were vigorously shaken, and the obtained suspensions were used to determine the number of conidia produced, with the aid of a Neubauer chamber. The yield and viability of conidia formed in the liquid medium were also determined by collecting $1 \mathrm{~mL}$ of the suspension used to seed the solid medium.

The conidial viability was determined as described by Francisco et al. (2006). Sterile microscope slides were covered with a thin layer of modified minimal Pontecorvo medium. In three regions of the culture medium, corresponding to areas previously marked in the slide, one drop of the designated fungus suspension was inoculated. The slides were kept in an incubator, at $25^{\circ} \mathrm{C} \pm 0.5^{\circ} \mathrm{C}$, and, after 7 hours, 150 conidia per region were observed under an optical microscope, to determine the germinated or not germinated ones, in order to obtain the percentage of viable conidia. Three replicate slides were used for each suspension.

Aiming to increase the yield of this production method, suspensions were obtained from the liquid medium fungal culture, as previously described. Different suspension volumes $(1 \mathrm{~mL}, 3 \mathrm{~mL}, 5 \mathrm{~mL}$, $7 \mathrm{~mL}$ and $9 \mathrm{~mL}$ ) were inoculated in the solid medium. The flasks were maintained at $25^{\circ} \mathrm{C} \pm 0.5^{\circ} \mathrm{C}$, with a photoperiod of 12 hours. The conidia yield and viability were evaluated as already described, after specific incubation periods, in the biphasic culture system.

The solid medium containing the cultured fungus was subjected to different conditions, for drying to a constant mass, while attempting to maintain conidial integrity. The following conditions were evaluated: a) oven temperatures $\left(30^{\circ} \mathrm{C}, 35^{\circ} \mathrm{C}\right.$, $40^{\circ} \mathrm{C}, 45^{\circ} \mathrm{C}, 50^{\circ} \mathrm{C}, 55^{\circ} \mathrm{C}$ and $\left.60^{\circ} \mathrm{C}\right)$; b) laminar flow at room temperature; c) aseptic chamber at room temperature; d) continuous air flow at room temperature (pressure of $3.5 \pm 0.3 \mathrm{kgf} \mathrm{cm}^{-2}$ and flow rate of $15 \mathrm{~L} \mathrm{min.}^{-1}$ ). In all conditions (except for the "d" condition, which used a container connected to the drying equipment), the material was arranged on plastic trays previously disinfected with ethanol $96^{\circ} \mathrm{GL}$. The room temperature ranged from $24^{\circ} \mathrm{C}$ to $27^{\circ} \mathrm{C}$, during the drying procedure.

The conidia viability, before and after the drying process, was evaluated, as well as the degree of water loss. For the latter parameter, a relationship (expressed as percentage) was established between the initial and final weight of the material evaluated. To assess the viability before and after drying, suspensions containing $1 \mathrm{~g}$ of solid medium + fungus and $9 \mathrm{~mL}$ of Tween $80^{\circledR}$ solution $\left(0.1 \% \mathrm{v} \mathrm{v}^{-1}\right)$ were prepared, and the test was performed according to the method described by Francisco et al. (2006).

The medium containing fungus, cultured and dried according to the methodology described above, was subjected to three grinding processes and to simple sieving, in order to obtain the conidia. The nature of the solid substrates used to produce the fungus allowed reducing these materials to a fine powder containing conidia (this reduction was not required for sieving).

The following equipments were used to obtain a fine powder: a) a ball mill (Marconi, model 
MA-350) with closed chamber; b) a hammer mill (Metalúrgica Roma, model MR-320) containing four hammers and a $1 \mathrm{~mm}$ sieve; c) a grain grinder (Arbel, model MCF-55). To extract the conidia by sieving, a sieve with $1 \mathrm{~mm}$ mesh was closed and shaken manually, for 10 minutes. The material obtained after this treatment was then passed through a sieve with $0.25 \mathrm{~mm}$ mesh, in order to remove impurities. In the ball mill method, the material was added to a grinding bowl and subjected to intermittent beats, for 1 minute. In the grain grinder, the regulator bushing was adjusted, so that the grinders would reduce the material to a fine powder. Grinding was performed twice, to achieve a fine powder.

The conidial viability was evaluated before and after each of the conidia collecting methods tested. Suspensions were made from a sample $(1 \mathrm{~g})$ of dried material, before grinding, or from $1 \mathrm{~g}$ of powder obtained after grinding. The samples were then transferred to test tubes containing $9 \mathrm{~mL}$ of Tween $80^{\circledR}$ solution $\left(0.1 \% \mathrm{v} \mathrm{v}^{-1}\right)$. For the conidia extracted by sieving, $0.1 \mathrm{~g}$ of material diluted in $9.9 \mathrm{~mL}$ of Tween $80^{\circledR}$ solution $\left(0.1 \% \mathrm{v} \mathrm{v}^{-1}\right)$ was used. The conidia viability was determined as described by Francisco et al. (2006).

Statistical analysis was conducted with the aid of the ESTAT (1997) software, version 2.0. The experimental design was completely randomized (CRD) and the data (four replicates per treatment) were subjected to analysis of variance, by using the F test, and means were compared by the Tukey's test, at $5 \%$. For conidia drying and collecting assays, a factorial design was used, with two factors: drying methods versus evaluation point (before and after drying), and collecting methods versus evaluation point (before and after collecting).

\section{RESULTS AND DISCUSSION}

Independently of whether the B. euphorbiae was grown on solid medium or in the liquid and solid phases of the biphasic system, the incubation time exerted no influence on the viability of the conidia produced $(\mathrm{p} \geq 0.05)$, and germination efficiency remained above $97 \%$, for all treatments (Tables 1 and 2).

For cultivation on solid medium, the fungus sporulation, after 14 days of culture, showed the greatest numerical value for this parameter $\left(8.9 \times 10^{7}\right.$ conidia $\mathrm{g}^{-1}$ of substrate), but was significantly different
Table 1. Conidial production and viability of Bipolaris euphorbiae on solid medium, at different incubation periods (Jaboticabal, São Paulo State, Brazil, 2011).

\begin{tabular}{ccc}
\hline Incubation period & Sporulation & Viability \\
\hline days & ${\mathrm{x} 10^{7} \text { conidia } \mathrm{g}^{-1}}^{\circ}$ & $\%$ \\
\hline 5 & $1.7 \mathrm{~B}$ & $97.5 \mathrm{~A}$ \\
6 & $2.4 \mathrm{AB}$ & $98.3 \mathrm{~A}$ \\
7 & $4.7 \mathrm{AB}$ & $97.9 \mathrm{~A}$ \\
8 & $5.4 \mathrm{AB}$ & $99.4 \mathrm{~A}$ \\
9 & $6.7 \mathrm{AB}$ & $99.1 \mathrm{~A}$ \\
10 & $8.3 \mathrm{AB}$ & $98.8 \mathrm{~A}$ \\
11 & $7.3 \mathrm{AB}$ & $99.5 \mathrm{~A}$ \\
12 & $7.0 \mathrm{AB}$ & $99.5 \mathrm{~A}$ \\
13 & $8.0 \mathrm{AB}$ & $99.4 \mathrm{~A}$ \\
14 & $8.9 \mathrm{~A}$ & $99.4 \mathrm{~A}$ \\
\hline F test & $2.52^{*}$ & $2.91^{*}$ \\
\hline C.V. $(\%)$ & 31.09 & 0.89 \\
\hline
\end{tabular}

Means with the same letters in the columns do not differ from each other by the Tukey's test $(\mathrm{p} \leq 0.05)$. Original values, but statistical analysis performed with transformed data to $\log (x+1)$ and arcsine $\sqrt{x} / 100$, respectively for sporulation and viability. $*$ Significant at $5 \%$.

only when compared to the sporulation obtained

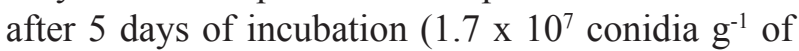
substrate) (Table 1).

Aiming at fungus mass production and obtaining large conidia quantities, the incubation for 10 days resulted in the most optimal "sporulation with high viability versus incubation period" relationship, although not significantly different from most the other incubation periods. Considering these data (Table 1), a 10-days incubation period would theoretically allow 3 production cycles, within a 30days period, and would reach $24.9 \times 10^{7}$ conidia $^{-1}$ of substrate. For an incubation period of 14 days, which provided the greatest numerical value for sporulation in this assay, 2 cycles would be completed within 30 days, finally yielding $17.8 \times 10^{7}$ conidia $\mathrm{g}^{-1}$ of substrate. The mean daily sporulation achieved in the first hypothetical situation would be $32 \%$ higher, suggesting that a 10-days incubation period would be optimal for producing the fungus.

The sporulation rate obtained with a 10-days incubation period $\left(8.3 \times 10^{7}\right.$ conidia $^{-1}$ of substrate $)$ was higher than that observed by Moraes (2009): $2.3 \times 10^{7}$ conidia $\mathrm{g}^{-1}$ of substrate, under the same conditions. This difference is likely due to variations in the substrate quality of the solid media, as they were made at different times.

Production systems using submerged liquid culture are widely used for the mass production 
Table 2. Conidial production and viability of Bipolaris euphorbiae on liquid and solid medium, at different incubation periods (Jaboticabal, São Paulo State, Brazil, 2011).

\begin{tabular}{|c|c|c|c|c|}
\hline \multirow{2}{*}{$\begin{array}{l}\text { Incubation } \\
\text { period }\end{array}$} & \multicolumn{2}{|c|}{ Liquid medium } & \multicolumn{2}{|c|}{ Solid medium $^{1}$} \\
\hline & Sporulation & Viability & Sporulation & Viability \\
\hline days & x $10^{5}$ conidia $\mathrm{mL}^{-1}$ & $\%$ & x $10^{5}$ conidia $\mathrm{mL}^{-1}$ & $\%$ \\
\hline 3 & $1.9 \mathrm{~B}$ & $99.5 \mathrm{~A}$ & - & - \\
\hline 4 & 4.0 AB & $99.7 \mathrm{~A}$ & - & - \\
\hline 5 & $3.8 \mathrm{AB}$ & $99.8 \mathrm{~A}$ & $1.0 \mathrm{~B}$ & $98.9 \mathrm{~A}$ \\
\hline 6 & $5.1 \mathrm{AB}$ & $99.8 \mathrm{~A}$ & $2.2 \mathrm{AB}$ & $99.2 \mathrm{~A}$ \\
\hline 7 & $6.1 \mathrm{~A}$ & $99.9 \mathrm{~A}$ & $4.5 \mathrm{~A}$ & $98.7 \mathrm{~A}$ \\
\hline 8 & 4.8 AB & $99.7 \mathrm{~A}$ & $4.0 \mathrm{~A}$ & $98.7 \mathrm{~A}$ \\
\hline 9 & $5.1 \mathrm{AB}$ & $99.4 \mathrm{~A}$ & $3.2 \mathrm{~A}$ & $98.9 \mathrm{~A}$ \\
\hline 10 & $5.0 \mathrm{AB}$ & $99.3 \mathrm{~A}$ & $3.7 \mathrm{~A}$ & $98.8 \mathrm{~A}$ \\
\hline F test & $2.44^{*}$ & $3.1 *$ & $5.86 * *$ & $2.63^{\mathrm{ns}}$ \\
\hline C.V. $(\%)$ & 30.23 & 0.24 & 24.3 & 0.24 \\
\hline
\end{tabular}

${ }^{1}$ Inoculum obtained after 7 days of incubation in liquid medium. Original values, but statistical analysis performed with transformed data to log ( $\left.\mathrm{x}+1\right)$ and arcsine $\sqrt{ } \mathrm{x} / 100$, respectively for sporulation and viability. ${ }^{\text {ns }}$ Non significant. $* *$ and $*$ : Significant at $1 \%$ and $5 \%$, respectively.

of bioherbicides (Churchill 1982, Stowell 1991), however, with $B$. euphorbiae, sporulation in liquid medium without agitation and with different incubation periods yielded $10^{5}$ conidia $\mathrm{mL}^{-1}$ (Table 2 ). Based on the data analysis, and considering that the fungus produced in this liquid phase was used as the inoculum for the second phase of the biphasic culture system, an incubation period of 7 days was chosen because it had the greatest observed numerical value $\left(6.1 \times 10^{5}\right.$ conidia $\left.\mathrm{mL}^{-1}\right)$ for fungal sporulation, despite not statistically different from most other values. In culture on solid medium, incubation for the same period also provided the greatest numerical sporulation value, although not significantly different $(p \geq 0.05)$ from any other tested growth period, except for 3 days (Table 2). Data analysis suggests that the production of $B$. euphorbiae in the biphasic culture system would optimally require a total of 14 days, whereas Moraes (2009) used 17 days.

Sporulation was significantly higher when $7 \mathrm{~mL}$ or $9 \mathrm{~mL}$ of fungal suspension was used to seed the solid phase (Table 3). However, the amount of inoculum may not be responsible for the greater sporulation of the fungus in the biphasic system. The conidia production, even with larger inoculum, was $28.9 \%$ lower than that obtained with the cultivation only on solid medium (Table 1). In addition, seeding the substrate in three separate flasks, with $3 \mathrm{~mL}$ inoculum each, would theoretically make it possible to obtain a total production of $8.7 \times 10^{7}$ conidia $^{-1}$ of substrate, which is greater than that obtained by seeding the substrate in a single flask with $9 \mathrm{~mL}$ inoculum $\left(5.9 \times 10^{7}\right.$ conidia $\mathrm{g}^{-1}$ of substrate $)$
Table 3. Conidial production and viability of Bipolaris euphorbiae in the biphasic system, after inoculating the solid phase with different amounts of inoculum from culture in the liquid phase (Jaboticabal, São Paulo State, Brazil, 2011).

\begin{tabular}{ccc}
\hline Inoculum quantity & Sporulation & Viability \\
\hline $\mathrm{mL}$ & ${\mathrm{x} 10^{7} \text { conidia } \mathrm{g}^{-1}}^{1}$ & $\%$ \\
\hline 1 & $1.5 \mathrm{C}$ & $98.7 \mathrm{~A}$ \\
3 & $2.9 \mathrm{~B}$ & $99.0 \mathrm{~A}$ \\
5 & $3.6 \mathrm{AB}$ & $98.9 \mathrm{~A}$ \\
7 & $4.1 \mathrm{AB}$ & $98.8 \mathrm{~A}$ \\
9 & $5.9 \mathrm{~A}$ & $98.8 \mathrm{~A}$ \\
\hline F test & $13.17^{*}$ & $0.73^{\text {ns }}$ \\
\hline C.V. $(\%)$ & 13.7 & 0.91 \\
\hline
\end{tabular}

Means with the same letters in the columns do not differ from each other by the Tukey's test $(\mathrm{p} \leq 0.05)$. Original values, but statistical analysis performed with transformed data to $\log (\mathrm{x}+1)$ and $\operatorname{arcsine} \sqrt{\mathrm{x}} / 100$, respectively for sporulation and viability. ${ }^{*}$ Significant at $5 \%$. ${ }^{\text {ns }}$ Non significant.

(Table 3). This is an industrially important aspect to consider.

Comparing the method of fungus production on solid medium and the biphasic system (Tables 1 and 2), the best sporulation versus incubation relationship was obtained by the cultivation on solid medium, which not only reduced the incubation time, but also provided a greater fungal sporulation. The process of removing $8 \mathrm{~mm}$ discs from plates containing the fungus may be less disruptive than grinding the mycelial mass in liquid medium, thus allowing faster and more efficient colonisation of the solid medium. Notably, the process of production on solid medium currently used in Brazil is simple and minimally automated, and yet it is efficient and cost compatible 
with the national production structure (Morandi \& Bettiol 2009).

The analysis of variance showed that the interaction of drying methods versus evaluation point was significant $(\mathrm{F}=48.80 * *)$. The examination of this interaction (Table 4) allowed assessing the effect of drying methods on the conidia. The germination rate before drying remained above $98 \%$, for all treatments, thereby ensuring sample homogeneity.

The most significant effects of the drying method on conidia were obtained for oven temperatures at $55^{\circ} \mathrm{C}$ and $60^{\circ} \mathrm{C}$, which featured reductions in germination of $26.3 \%$ and $73.6 \%$, respectively. For all the other methods, the viability of conidia was generally preserved after drying and remained above $94 \%$ (Table 4 ), a satisfactory level of quality for a commercial product.

The purpose of drying the material is to reduce the available water to a level capable of maintaining the viability of conidia for the longest storage period possible. The continuous air flow drying method provided the greatest loss of moisture content, but it did not differ significantly from the laminar flow method or the oven at $50^{\circ} \mathrm{C}$ and $60^{\circ} \mathrm{C}$ (Table 5).

Among the drying methods used in the present study, the continuous air flow and laminar flow can be considered the most suitable for drying $B$. euphorbiae conidia, because they provided a great moisture loss, while maintaining the conidia viability. The physical structure of the material used, containing large

Table 4. Conidial viability of Bipolaris euphorbiae, regarding significance of results and considering the interaction drying methods versus evaluation point (Jaboticabal, São Paulo State, Brazil, 2011).

\begin{tabular}{lccc}
\hline \multirow{2}{*}{ Drying method } & \multicolumn{2}{c}{ Conidial viability (\%) } & \multirow{2}{*}{ F test } \\
\cline { 2 - 3 } & \multicolumn{2}{c}{ Evaluation point } & \\
\cline { 2 - 3 } & Before drying & After drying & \\
\hline Laminar flow $^{1}$ & $99.6 \mathrm{Aa}$ & $99.1 \mathrm{ABa}$ & $0.72^{\text {ns }}$ \\
Continuous air flow & $98.9 \mathrm{Aa}$ & $94.6 \mathrm{Bb}$ & $9.13^{* *}$ \\
Aseptic chamber & $98.9 \mathrm{Aa}$ & $98.7 \mathrm{ABa}$ & $0.08^{\mathrm{ns}}$ \\
Oven at $30^{\circ} \mathrm{C}$ & $98.9 \mathrm{Aa}$ & $99.4 \mathrm{Aa}$ & $0.01^{\mathrm{ns}}$ \\
Oven at $35^{\circ} \mathrm{C}$ & $98.4 \mathrm{Aa}$ & $97.3 \mathrm{ABa}$ & $0.74^{\mathrm{ns}}$ \\
Oven at $40^{\circ} \mathrm{C}$ & $99.2 \mathrm{Aa}$ & $99.4 \mathrm{Aa}$ & $0.04^{\mathrm{ns}}$ \\
Oven at $45^{\circ} \mathrm{C}$ & $98.6 \mathrm{Aa}$ & $99.2 \mathrm{Aa}$ & $0.02^{\text {ns }}$ \\
Oven at $50^{\circ} \mathrm{C}$ & $99.3 \mathrm{Aa}$ & $96.9 \mathrm{ABb}$ & $5.52^{*}$ \\
Oven at $55^{\circ} \mathrm{C}$ & $98.9 \mathrm{Aa}$ & $72.9 \mathrm{Cb}$ & $97.82^{* *}$ \\
Oven at $60^{\circ} \mathrm{C}$ & $99.2 \mathrm{Aa}$ & $26.2 \mathrm{Db}$ & $473.65^{* *}$ \\
\hline F test & $0.39^{\mathrm{ns}}$ & $98.56^{* *}$ & \\
\hline
\end{tabular}

${ }^{1}$ Room temperature. Original values, but statistical analysis performed with transformed data to arcsine $\sqrt{x} / 100$. Means followed by the same capital letter in the column or small letter in the line do not differ from each other by the Tukey's test $(\mathrm{p} \leq 0.05) .{ }^{\text {ns }}$ Non significant. $* *$ and $*$ : Significant at $1 \%$ and $5 \%$, respectively.
Table 5. Moisture loss by material from fungal culture on solid medium, after different drying methods (Jaboticabal, São Paulo State, Brazil, 2011).

\begin{tabular}{lc}
\hline \multicolumn{1}{c}{ Drying method } & Moisture content loss (\%) \\
\hline Laminar flow $^{1}$ & $54.00 \mathrm{AB}$ \\
Continuous air flow $^{1}$ & $62.65 \mathrm{~A}$ \\
Aseptic chamber & $34.55 \mathrm{C}$ \\
Oven at $30^{\circ} \mathrm{C}$ & $21.70 \mathrm{D}$ \\
Oven at $35^{\circ} \mathrm{C}$ & $22.90 \mathrm{D}$ \\
Oven at $40^{\circ} \mathrm{C}$ & $24.38 \mathrm{D}$ \\
Oven at $45^{\circ} \mathrm{C}$ & $45.37 \mathrm{BC}$ \\
Oven at $50^{\circ} \mathrm{C}$ & $50.66 \mathrm{AB}$ \\
Oven at $55^{\circ} \mathrm{C}$ & $48.99 \mathrm{~B}$ \\
Oven at $60^{\circ} \mathrm{C}$ & $54.62 \mathrm{AB}$ \\
\hline F test & $38.12^{* *}$ \\
\hline C.V. $(\%)$ & 5.62 \\
\hline${ }^{1}$ Room temperature. Original values, but statistical analysis performed with \\
transformed data to log 5. ${ }^{* *}$ Significant at $1 \%$.
\end{tabular}

surface area and absence of aggregation, possibly facilitated the aeration by drying methods that did not use oven, allowing greater removal of water, which is important for the conidia preservation. Temperatures of $55-60^{\circ} \mathrm{C}$ also provided great moisture loss, but caused a large reduction in the conidia viability (Tables 4 and 5). These temperatures may have altered the biochemical components of the metabolic machinery of the conidium, thereby negatively affecting its germination.

Tolerance to drying is a factor that may limit the success and trade of bioherbicides (Montazeri \& Greaves 2002). The decrease in the metabolic activity of conidia reduces the viability loss during storage and minimises the production of toxic metabolites (Guijarro et al. 2006). Reports in literature suggest that the ideal moisture content for substrates containing conidia ranges from $10 \%$ to $30 \%$ (Silva \& Mello 2007, Lomer \& Lomer 1998).

The drying methods often used by the industry to process products based on microorganisms are freeze drying, spray drying and fluidised bed drying (Jin \& Custis 2011). The differences between the technology and equipment used by these methods and those used in the present study greatly complicate the comparison of results. Nevertheless, the reduction observed in the B. euphorbiae viability, after drying at the highest temperatures, was also observed when other pathogens were dried by using other aforementioned common methods (Larena et al. 2003, Horaczek \& Viernstein 2004), with subsequent irreversible damage to the biological materials, due 
to excessive heat and water loss (Daemen \& Van der Stege 1982). The drying methods used in the present study may not provide the ideal moisture content for substrates containing conidia, however, their simplicity can help to reduce the production cost of a bioherbicide based on $B$. euphorbiae.

The data analysis showed that the interaction of collecting methods versus evaluation point was significant, and that this interaction affected the conidia viability.

There was no significant difference in the germination of previously dried conidia, before they were subjected to the various collecting methods, showing that all treatments, initially, had viable particles (Table 6). Methods of collecting conidia by milling caused damage to the physical structure and integrity of conidia, as verified with microscope observation, thus significantly reducing their germination. This effect was especially pronounced when using the ball mill, which reduced germination by $86.2 \%$. The aggressiveness of this method is due to the intermittent impact of a stainless steel ball against the milling chamber wall, which reduces the samples to a fine powder. The grain grinder and hammer mill reduced, respectively, $12.0 \%$ and $10.5 \%$ the conidia germination. Collecting conidia by sieving, although simple to perform, was the most appropriate method, allowing the extraction of high viability conidia (Table 6).

Studies performed to evaluate conidia extraction methods were not found in literature, fact that illustrates the need to investigate this preliminary stage in the process of formulating bioproducts. It is important to consider that the method for collecting

Table 6. Conidial viability of Bipolaris euphorbiae, regarding significance of results and considering the interaction collecting methods versus evaluation point (Jaboticabal, São Paulo State, Brazil, 2011).

\begin{tabular}{|c|c|c|c|}
\hline \multirow{3}{*}{$\begin{array}{l}\text { Collecting } \\
\text { method }\end{array}$} & \multicolumn{2}{|c|}{ Conidial viability (\%) } & \multirow{3}{*}{$\mathrm{F}$ test } \\
\hline & \multicolumn{2}{|c|}{ Evaluation point } & \\
\hline & Before collecting ${ }^{1}$ & After collecting & \\
\hline Grain grinder & $88.92 \mathrm{Aa}$ & $78.33 \mathrm{Bb}$ & $8.2038 * *$ \\
\hline Hammer mill & $93.85 \mathrm{Aa}$ & $83.95 \mathrm{Bb}$ & $10.4640 * *$ \\
\hline Ball mill & $91.20 \mathrm{Aa}$ & $12.60 \mathrm{Cb}$ & $340.1616 * *$ \\
\hline Sieving & $94.87 \mathrm{Aa}$ & $94.82 \mathrm{Aa}$ & $0.0086^{\mathrm{ns}}$ \\
\hline F test & $2.0076^{\mathrm{ns}}$ & $151.3616^{* * *}$ & \\
\hline \multicolumn{4}{|c|}{$\begin{array}{l}\text { Drying the material containing the fungus under continuous air flow (room } \\
\text { temperature). Original values, but statistical analysis performed with transformed } \\
\text { data to arcsine } \sqrt{x} / 100 \text {. Means followed by the same capital letter in the column or } \\
\text { small letter in the line do not differ from each other by the Tukey's test }(\mathrm{p} \leq 0.05 \text { ). } \\
\text { ns Non significant. } * * \text { Significant at } 1 \% \text {. }\end{array}$} \\
\hline
\end{tabular}

conidia must be compatible with the type of formulation desired. Irrespective of the formulation, the product should first be subjected to drying, to ensure that the conidia will remain viable during storage (Lomer \& Lomer 1998).

\section{CONCLUSIONS}

1. The incubation period influenced the production of $B$. euphorbiae cultivated both on the solid medium and in the biphasic system, such that the optimal incubation period was 10 days for the solid medium and 14 days for the biphasic system.

2. The amount of liquid inoculum used to seed the solid phase did not increase the production of $B$. euphorbiae by the biphasic system, when compared to the cultivation only on solid medium.

3. The B. euphorbiae viability was influenced by the method for drying the fungus and collecting the conidia.

\section{ACKNOWLEDGEMENTS}

To the Coordenação de Aperfeiçoamento de Pessoal de Nível Superior (Capes), for granting a scholarship to the first author.

\section{REFERENCES}

ALMEIDA, J. E. M.; ROCHA, T. C.; BATISTA FILHO, A. Desenvolvimento de método para extração física de conídios de Metarhizium anisopliae e Beauveria bassiana para formulação de pó seco e molhável de bioinseticida. Arquivos do Instituto Biológico, São Paulo, v. 74, n. 4, p. 369-371, 2007.

BARRETO, R. W. Controle biológico de plantas daninhas com fitopatógenos. In: BETTIOL, W.; MORANDI, M. A. B. (Eds.). Biocontrole de doenças de plantas: uso e perspectivas. Jaguariúna: Embrapa Meio Ambiente, 2009. p. 101-128.

BARRETO, R. W.; EVANS, H. C. Fungal pathogens of Euphorbia heterophylla and E. hirta in Brazil and their potential as weed biocontrol agents. Mycopathologia, The Hague, v. 141, n. 1, p. 21-36, 1998.

BRIGHENTI, A. M.; OLIVEIRA, M. F. Biologia de plantas daninhas. In: OLIVEIRA JÚNIOR, R. S.; CONSTANTIN, J.; INOUE, M. H. (Eds.). Biologia e manejo de plantas daninhas. Curitiba: Omnipax, 2011. p. 7-8.

CHURCHILL, B. W. Mass production of microorganisms for biological control of weeds with plant pathogens. In: 
CHARUDATTAN, R.; WALKER, H. L. (Eds.). Biological control of weeds with plant pathogens. New York: John Willy \& Sons, 1982. p. 139-156.

DAEMEN, A. L. H.; VAN DER STEGE, H. J. The destruction of enzymes and bacteria during the spray drying of milk and whey: 2 . The effect of the drying conditions. Netherlands Milk and Dairy Journal, Wageningen, v. 36, n. 3, p. 211-229, 1982.

ESTAT: sistema para análise estatística. Versão 2.0. Jaboticabal: Faculdade de Ciências Agrárias e Veterinárias, 1997.

FONTES, E. M. G. Controle biológico: um desafio para o País. Pesquisa Agropecuária Brasileira, Brasília, DF, v. 27, n. 1, p. 1-4, 1992.

FRANCISCO, E. A. et al. Influence of culture media in viability test of conidia of entomopathogenic fungi. Ciência Rural, Santa Maria, v. 36, n. 4, p. 1309-1312, 2006.

GUIJARRO, B. et al. Effect of drying on conidial viability of Penicillium frequentans, a biological control agent against peach brown rot disease caused by Monilinia spp. Biocontrol Science and Technology, Abingdon, v. 16, n. 3, p. 257-269, 2006.

HORACZEK, A.; VIERNSTEIN, H. Comparison of three commonly used drying technologies with respect to activity and longevity of areal conidia of Beauveria brongniartii and Metarhizium anisopliae. Biological Control, San Diego, v. 31, n. 1, p. 65-71, 2004.

JIN, X.; CUSTIS, D. Microencapsulating aerial conidia of Trichoderma harzianum through spray drying at elevated temperatures. Biological Control, San Diego, v. 56, n. 2, p. 202-208, 2011.

LARENA, I.; MELGAREJO, P.; DE CAL, A. Drying of conidia of Penicillium oxalicum, a biological control agent against Fusarium wilt of tomato. Journal of Phytopathology, Berlin, v. 151, n. 11-12, p. 600-606, 2003.

LIMA, B. V.; SOARES, D. J.; BARRETO, R. W. Inocullum density of Plectosporium alismatis, a potential mycoherbicide, in relation to control of the aquatic weed Sagittaria montevidensis. Tropical Plant Pathology, Lavras, v. 35, n. 4, p. 239-240, 2010.

LOMER, C. H.; LOMER, C. J. (Eds.). Mass production of fungal pathogenes for insect control: insect pathology manual. 1998. Available at: <http://www.lubilosa.org/ Eng107a.PDF>. Access on: 06 Nov. 2012.

LORENZI, H. Plantas daninhas no Brasil. Nova Odessa: Plantarum, 2000.

MACHADO, A. C. R. et al. Production technology for entomopathogenic fungus using a biphasic culture system. Pesquisa Agropecuária Brasileira, Brasília, DF, v. 45, n. 10 , p. $1157-1163,2010$.

MOINO JÚNIOR, A. Produção de fungos, vírus e bactérias entomopatogênicas. In: BUENO, V. H. P. (Ed.). Controle biológico de pragas: produção massal e controle de qualidade. Lavras: Ed. da UFLa, 2000. p. 186-193.

MONTAZERI, M.; GREAVES, M. P. Effects of nutrition on desiccation tolerance and virulence of Colletotrichum truncatum and Alternaria alternata conidia. Biocontrol Science and Technology, Abingdon, v. 12, n. 2, p. 173181, 2002.

MORAES, C. Produção massal e influência de fatores físicos no cultivo e viabilidade de Bipolaris euphorbiae. 2009. 75f. Dissertação (Mestrado em Microbiologia Agropecuária) - Faculdade de Ciências Agrárias e Veterinárias, Universidade Estadual Paulista, Jaboticabal, 2009.

MORANDI, M. A. B.; BETTIOL, W. Controle biológico de doenças de plantas daninhas no Brasil. In: BETTIOL, W.; MORANDI, M. A. B. (Eds.). Biocontrole de doenças de plantas: uso e perspectivas. Jaguariúna: Embrapa Meio Ambiente, 2009. p. 7-14.

MUZIK, T. J. Weed biology and control. New York: McGraw-Hill, 1970.

OLIVEIRA JÚNIOR, R. S.; INOUE, M. H. Seletividade de herbicidas para culturas e plantas daninhas. In: OLIVEIRA JÚNIOR, R. S.; CONSTANTIN, J.; INOUE, M. H. Biologia e manejo de plantas daninhas. Curitiba: Omnipax, 2011. p. 243-262.

PENARIOL, M. C. et al. Produção de Bipolaris euphorbiae em meios de cultura sólidos e líquidos obtidos de grãos e resíduos agroindustriais. Bragantia, Campinas, v. 67, n. 4, p. $805-814,2008$.

PONTECORVO, G. et al. The genetics of Aspergillus nidulans. Advances in Genetics, New York, v. 5, n. 1, p. 141-238, 1953.

SILVA, J. B. T.; MELLO, S. C. M. Utilização de Trichoderma no controle de fungos fitopatogênicos. Brasília, DF: Embrapa Recursos Genéticos e Biotecnologia, 2007.

STOWELL, L. J. Submerged fermentation of biological herbicides. In: TEBEEST, D. O. (Ed.). Microbial control of weeds. New York: Chapman \& Hall, 1991. p. 225-261.

TREZZI, M. M. et al. Multiple resistance of acetolactase synthase and protoporphyrinogen oxidase inhibitors in Euphorbia heterophylla biotypes. Journal of Environmental Science and Health, New York, v. 40, n. 1, p. 101-109, 2005.

VIDAL, R. A.; MEROTTO JÚNIOR, A. Resistência de amendoim-bravo aos herbicidas. In: VIDAL, R. A.; MEROTTO JÚNIOR, A. (Eds.). Herbicidologia. Porto Alegre: Evangraf, 2001. p. 138-148.

VIDAL, R. A. et al. Glyphosate resistant biotypes of wild poinsettia (Euphorbia heterophylla L.) and its risk analysis on glyphosate-tolerant soybeans. Journal of Food, Agriculture and Environment, Helsinki, v. 5, n. 2, p. 265-269, 2007. 